\title{
Translation of forms of address from Portuguese to Turkish through English: The case of José Saramago's A Jangada de Pedra
}

\author{
İmren Gökce Vaz de Carvalho (D) \\ NOVA University Lisbon and University of Aveiro, Portugal
}

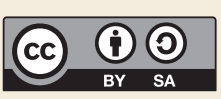

\begin{abstract}
The study of forms of address in translation is a type of register analysis that provides an interesting insight into the way specific linguistic patterns are transferred from one language to another. This article explores how the forms of address are rendered in the Turkish translation of A Jangada de Pedra (1986) by the Portuguese author José Saramago. Paratextual and textual analyses demonstrate that this work has been translated into Turkish through the English translation of the book, and that the English translation has influenced the choices of the Turkish translator. The findings of the study seem to support the hypothesis that using a mediating language/text that lacks similar forms of address as the ultimate source and the target languages/texts can cause shifts in tenor, which results in a different reading of interpersonal relationships between fictional characters in the target text.
\end{abstract}

Keywords: register, indirect translation, José Saramago, discourse analysis, forms of address

\section{Oblike naslavljanja v prevodu iz portugalščine v turščino prek angleščine na primeru $A$ Jangada de Pedra Joséja Saramaga}

\section{IZVLEČEK}

Študija oblik naslavljanja predstavlja vrsto analize registra, ki omogoča zanimiv vpogled v to, kako se specifični jezikovni vzorci prenašajo iz enega jezika v drugega. Članek se osredotoča na to, katere oblike naslavljanja najdemo v turškem prevodu A Jangada de Pedra (1986) portugalskega avtorja Joséja Saramaga. Iz analize paratekstov in besedilne analize je razvidno, da je bilo omenjeno delo prevedeno v turščino posredno prek angleškega prevoda, hkrati pa se pokaže, da je angleški prevod vplival na prevajalske odločitve turškega prevajalca. Izsledki študije pritrdijo hipotezi, da zaradi posrednega jezika/besedila, v katerem ni podobnih oblik naslavljanja, kot so tiste, ki se pojavljajo v primarnem izvirnem jeziku/besedilu in v ciljnem jeziku/besedilu, lahko pride do premikov v tonu, zaradi katerih se spremeni interpretacija medsebojnih odnosov med literarnimi liki v ciljnem jeziku.

Ključne besede: register, posredni prevod, José Saramago, analiza diskurza, oblike naslavljanja 


\section{Introduction}

The case study presented in this article aims to show how the use of English as a mediating language may influence the register of the target text. For this purpose, a Portuguese novel by José Saramago, A Jangada de Pedra, and its Turkish translation will be compared to its English translation, specifically looking at the forms of address used to express various levels of tenor in the source text and Turkish target text.

Before going into the depths of this study, it is necessary to clarify some concepts related to indirect translation, forms of address and register. First of all, indirect translation, in this study, refers to a translation which has been done using a translation as a source text (Assis Rosa, Pieta, and Maia, 2017). In this article, the mediating source text is understood as a translation in its own right, that is, a translation that was translated for its own audience and was not produced for the purpose of further translations. Furthermore, "the ultimate ST/SL > mediating text/language > ultimate TT/TL" designation is used in this study while referring to the chain of texts and languages, following Assis Rosa, Pieta, and Maia's (2017, 115; italics in the original) suggestion.

Secondly, in order to understand how forms of address function and their importance for translation, their place in register analysis should be understood. Register refers to the differences in the use of linguistic choices such as use of vocabulary, grammatical structures, pronouns, and so on within different contexts and situations (Halliday, McIntosh, and Strevens 1964; Hatim and Mason 1990). Register analysis provides us with the linguistic patterns used in a given culture/society within its sociocultural context (Munday and Zhang 2017, 3). It is also one of the pivotal components of translator training as well as translation analysis and criticism, in that it allows us to access the necessary knowledge about ways of expression and possibilities within different sociocultural contexts. Munday and Zhang $(2017,3)$ emphasize the importance of register analysis for the translation process, stating that various registers "need to be identified, interpreted and translated in an appropriate way with due consideration given to language-specific differences and genre conventions".

According to the classification of register variables illustrated in Table 1, the term field refers to the "the field of activity", the experience that the participants are involved in, or in other words, "the kind of language use which reflects [...] the social function of the text" (Hatim and Mason 1990, 48). Examples of the field are medical or legal settings, literature and/or fictional settings, scientific or academic settings, educational settings, and so on, which means the field provides us with the situational context (Hatim and Mason 1990, 48). On the other hand, tenor refers to the way interlocutors interact, their backgrounds, social status in relation to each other, and their 
roles within the communicative action. Finally, with the term "mode" we describe the channel of communication, that is whether it is spoken or written, and permutations of this distinction, i.e. written to be spoken, written to be read, etc. (Hatim and Mason 1990, 49), as well as rhetorical concepts, i.e., if the discourse is persuasive, didactic, descriptive, and so on (ibid. 1990, 50).

Table 1. Register variables (Munday and Zhang 2017, 2).

\begin{tabular}{|l|l|l|}
\hline Register variable & $\begin{array}{l}\text { Associated discourse } \\
\text { semantic function }\end{array}$ & $\begin{array}{l}\text { Typical lexicogrammatical } \\
\text { realizations }\end{array}$ \\
\hline $\begin{array}{l}\text { Field (what the text is about } \\
\text { and how the experience is } \\
\text { represented) }\end{array}$ & Ideational, enacts action & $\begin{array}{l}\text { Subject-specific terminology } \\
\text { and transitivity structures }\end{array}$ \\
\hline $\begin{array}{l}\text { Tenor (the relationship } \\
\text { between participants and the } \\
\text { expression of evaluation) }\end{array}$ & Interpersonal, enacts affiliation & $\begin{array}{l}\text { Modality structures, pronoun } \\
\text { choices, evaluative lexis }\end{array}$ \\
\hline $\begin{array}{l}\text { Mode (the form of } \\
\text { communication: written or } \\
\text { spoken; formal or informal) }\end{array}$ & $\begin{array}{l}\text { Textual, distributes } \\
\text { information }\end{array}$ & $\begin{array}{l}\text { Thematic (word order) and } \\
\text { information structures, } \\
\text { patterns of cohesion }\end{array}$ \\
\hline
\end{tabular}

Among these register variables, translation of forms of address offers an interesting field to investigate due to the possible shifts in tenor resulting from the differences between languages and cultures. Forms of address or "address terms" are defined as pronominal, nominal, or verbal forms that are used to appeal directly to an addressee (Taavitsainen and Jucker 2003, 1). As suggested by Brown and Gilman (1960), the pronouns are used as indications of power and solidarity between participants of an interaction. Besides, forms of address used in an interaction between participants give clues about "the formality of the situation, the social relationship between the speaker and the addressee" and "the politeness or deference that the speaker wants to extend to the addressee" (Taavitsainen and Jucker, 2003, 2). Today, the abbreviations T and V, as introduced by Brown and Gilman $(1960,254)$, are used conventionally to refer to the second person singular pronoun, where $\mathrm{T}$ refers to the informal and familiar use and $\mathrm{V}$ refers to the more distant and polite use of address. The following table demonstrates the pronominal forms for the second person singular in some European languages: 
Table 2. T and V pronominal forms in some European languages, adapted from Taavitsainen and Jucker $(2003,4)$.

\begin{tabular}{|l|l|l|l|}
\hline Language & T & V & Origin of V \\
\hline Spanish & tu & Usted & Respectful title \\
\hline Italian & tu & Lei & $3^{\text {rd }}$ person singular \\
\hline Dutch & jij & U & Respectful title \\
\hline Polish & ty & Pan/pani & Respectful title \\
\hline German & du & Sie & $3^{\text {rd }}$ person plural \\
\hline French & tu & vous & $2^{\text {nd }}$ person plural \\
\hline Russian & ty & vy & $2^{\text {nd }}$ person plural \\
\hline Finnish & sinã & te & $2^{\text {nd }}$ person plural \\
\hline Turkish & Sen & Siz & $2^{\text {nd }}$ person plural \\
\hline Swedish & du & ni & $2^{\text {nd }}$ person plural \\
\hline
\end{tabular}

Although I am not aware of any studies addressing the translation of forms of address in indirect translation or in translation between the Portuguese and Turkish language pair, there is research addressing this issue between English and other languages, including Portuguese and Turkish, that can inform this study. For example, Baubeta (1992) shows that the formal forms of address that exist in Portuguese are rendered as you into English, and adds that translators may have difficulties in that they "may not always know" $(1992,91)$ if the party using the formal or informal forms of address does it deliberately. Baubeta $(1992,97)$ demonstrates this problem with an example from Saramago's Levantado do Chão, where the interrogator addresses the main character with second person singular verb forms possibly to "humiliate and intimidate him". Other examples she gives also show that translators can benefit from the use of vocabulary when translating into languages that do not offer alternatives for formal address pronouns and grammatical structures, and that translators need to be informed about the cultural, social, and linguistic differences between the languages concerned (Baubeta 1992). Lucena (1997) also demonstrates how differences in the address system between Brazilian Portuguese and English cause shifts between the ST and TT through examples drawn from the comparison of George Orwell's Animal Farm and its Portuguese translation. In another study, Assis Rosa (2000) investigates the translation of forms of address from English into Portuguese, analyzing a corpus of all versions of Robinson Crusoe, including direct and indirect translations, full text translations and adaptations. Although she does not investigate the influence of 
(in)directness of translation on translational choices, Assis Rosa $(2000,30)$ suggests that the shifts from English into Portuguese found in her study in general indicate a "tendency to bring the text closer to the implied reader and his social environment". On the other hand, Dinçkan's (2019) comparison of Little Women to its Turkish translation shows that the use of first name as an address form in English results in the use of the $\mathrm{T}$ form in the Turkish translation, while the use of formal titles such as $\mathrm{Mr} / \mathrm{Mrs} /$ Miss + last name in the original leads to the use of the $\mathrm{V}$ form in the Turkish translation. Apart from literature, translation of forms of address also seems to be a popular research area in audiovisual translation. ${ }^{1}$

All these studies exemplify that literary translators not only need to decipher situational and power related dynamics coded through the use of certain forms of address within the source text, they also need to decide how to recreate them in the target language. In other words, they may choose to render the conversations in the source text using the available more or less comparable forms in the target language, preserving the dynamics of interpersonal relations of the foreign culture, or they may opt for adapting them to the sociolinguistic context of the target culture. Nevertheless, the lack of formal pronominal forms for the second person singular, as it is the case in modern English, can make the decision-making process more difficult for translators. Therefore, shifts in the formality of address between the ultimate ST and the ultimate TT can be expected in an indirect translation where English is involved as the mediating language, especially if shifts in tenor are present in the mediating text compared to the ultimate ST. As Hadley $(2017,3)$ suggests "translations produced from texts that are also translations, and with no direct reference to those translations' sources, are inherently constrained by the stands and strategies taken by the first translations".

The case study presented in this article offers a comparison of A Jangada de Pedra written by the Portuguese author José Saramago and its Turkish translation. As the paratexts of the Turkish editions provide different information on the (in)directness of the translation in question, it seems important to use an independent method to verify the status of the translation, in this case. The article will therefore first argue that the status of the book as an indirect translation from the English translation can be confirmed through paratextual and textual analysis, and secondly, that the Turkish TT is heavily influenced by the English mediating translation. Afterwards, the article investigates the hypothesis that indirect translation between languages with various forms of address for the second person singular, such as Portuguese and Turkish through the mediation of a language that lacks these forms such as modern English causes shifts in tenor. It is

1 See Mansor (2018) for Malay-English, Meister (2014) for Swedish-English, and Szarkowska (2013) for Polish-English subtitling. 
further hypothesized that such shifts in tenor between the ultimate ST and ultimate TT result in differences in the established interpersonal relationships in literary texts, and hence lead to a different reading in source and target systems.

Selected examples will be analyzed to demonstrate the shifts in tenor between the Portuguese original and English and Turkish translations. A brief explanation of how forms of address function in European Portuguese and Turkish is provided below before describing and analyzing the corpus of the study.

\section{Forms of address in Portuguese and Turkish}

Both Portuguese and Turkish are quite rich languages in terms of the variety of forms used in formal and informal address between interlocutors. The use of nominal forms of address in various formal and informal contexts has been shown by previous research for Portuguese (see Carreira 1997, 2001, 2002, 2004, 2007; Cunha and Cintra 2014; Duarte 2011; Manole 2011; Lopes 2017; Nascimento, Mendes, and Duarte 2018; Pratas 2017; Allen 2019) and Turkish (See İmamova, 2010; Keser 2018; Y. Özezen 2019). This study, however, focuses on the use of verbal structures used in formal and informal contexts in Portuguese and Turkish.

The Portuguese way of addressing people is known to be one of the most complicated systems among European languages: it is mainly based on three different types of hierarchical relationship between interlocutors - social and professional, familial, and age difference (Carreira 2001, 71). Carreira (2001, 72-73) demonstrates various forms of expressing social distance in Portuguese, from the most informal to the most formal in a horizontal line with two poles: on the one side the least distant and most familiar, and on the other side the least familiar and most distant. As also shown by Duarte $(2011,87)$, the third person singular verb conjugation is the most common form of address in Portuguese. However, the use of this verb conjugation alone may not automatically signal distance, politeness, and/or respect. Third person singular verb forms are used in three different combinations (Duarte 2011, 87): a) with nominal forms, names, titles that are used to address the other interlocutor within a dialogue, e.g. O Senhor / A senhora Professora / A Dona Alves, O menino João, etc.; b) with the pronoun você [you]; and c) without any pronominal or nominal structures to avoid the possible misunderstanding that may result from the inappropriate use of the pronoun você, especially in European Portuguese (Duarte 2011, 87). The latter, that is, addressing another person by using only third person singular verb conjugations, is called "zero degree of deference" (Carreira 2001, 55). Nevertheless, according to Carreira $(2001,49)$, this use may also be deemed disrespectful when there is an age 
difference between interlocutors who are not known to each other. In modern European Portuguese, the pronoun $t u$ and the second person singular verb conjugations are reserved for family and close friends only.

On the other hand, according to Göksel and Kerslake $(2005,231)$, in Turkish the second person plural siz and the related verb conjugation are used as a formal form of address in the following contexts:

- When interlocutors do not know each other, and/or when they do not have a close relationship;

- When there is a hierarchical relationship between the interlocutors (e.g., students use siz to address their teachers while teachers usually use sen, the second person singular pronoun. In professional settings, however, both parties usually use siz);

- Younger people tend to address older people using siz.

However, it is important to note that the use of siz largely depends on the interlocutors' social / educational / cultural backgrounds (Göksel and Kerslake 2005). It is also worth mentioning here that contrary to what Göksel and Kerslake (2005) claim, addressing older people with siz is not so common in Turkey, instead, the second person singular pronoun sen and/or related verb conjugations together with nominal forms such as abla [elder sister], teyze [aunt], amca [uncle], dede [grandad], and so on is more common in informal settings, even though there is no or little familiarity between the interlocutors (Dinçkan 2019, 92; Kaya 2012, 301).

Although the distance and deference are closely tied to the use of various nominal address forms or pronouns in European Portuguese, there is no such difference in Turkish. In other words, the use of siz and/or second person plural verbal form does always indicate distance between interlocutors. In a similar vein, Karabaş and Yeşilçay (1977 quoted in Lewis 2000, 277) also show that addressing someone with siz and/or second person plural verb conjugation creates a barrier in rural Turkey, meaning "you and your lot as distinct from us intellectuals". On the other hand, deference and solidarity can be established with the use of the pronoun sen and/or related verb conjugation + the abovementioned nominal forms referring to kinship like abla [elder sister], teyze [aunt], yenge [aunt/sister-in-law], amca [uncle] and so on in informal settings, especially when an age difference is involved, even with complete strangers (Kaya 2012).

On the other hand, insisting on addressing the other party as sen in Turkish or $t u$ in Portuguese and/or related verbal forms may imply an effort to ignore the authority of the person they are talking to, and thus belittle or patronize them (Baubeta 1992), or to get closer to the addressee, especially from the part of male addressers in Turkish (Hatipoğlu 2008). 


\section{A Jangada de Pedra and its translations in Turkish and English}

In A Jangada de Pedra (1986), the Iberian Peninsula begins to sail into the Atlantic Ocean with a risk of crashing into the Azores after separating from continental Europe and ends up staying between South America and Africa. We read about the journey of the Iberian Peninsula through the story of five people and a dog that come together after realizing that they are mysteriously linked to the separation of the peninsula. Although it looks like a dystopian novel at the first glance, A Jangada de Pedra is actually a utopia that was imagined by the 1998 Nobel Laureate Portuguese writer José Saramago as an alternative to the joining of Portugal to the European Union (then European Economic Community) (Pazos-Justo 2017; Santos 2019). Saramago thought that Iberia was never culturally connected to the rest of Europe, and that the Iberian people were culturally and emotionally closer to Ibero-American and Ibero-African peoples (Arnaut 2014). The peninsula's drifting away from the continent and sailing across the ocean like the ships of great explorers in the past also revived the glorious memories of the time of the Discoveries, and of strong economic and cultural relations that started during that era (Arnaut 2014).

A Jangada de Pedra was first published in Turkey with the title Yitik Adanın Öyküsü [The Story of The Lost Island] in 1999 by the publisher Gendaş. The same translation was republished in 2006 by the publishing house Merkez, which later became known as Turkuvaz. The translation was republished in 2013, and continues to be reprinted by the final copyright holder of Saramago's works in Turkey, the publishing house Kırmızı Kedi.

This book was translated into Turkish by Dost Körpe, a writer and poet, and the translator of various works by Frank Herbert, Edgar Allan Poe, Ray Bradbury, H.P. Lovecraft, Henry James among many others. On the copyright page of Kirmız1 Kedi's edition of the novel he is introduced as a graduate of the department of English language and literature at Istanbul University. Since I was unable to interview him, I have searched for paratextual clues to verify my hypothesis that the book was translated from English. Although the translations published by the current publisher give no indication of the source text or language, the first publisher Gendaş introduced the translation as "İngilizceden çeviren" (translated from English by) on the title page, which would seem to confirm that the Turkish translation is an indirect translation done on the basis of the English version.

Textual analysis was then carried out, the aim of which was to confirm the indirect status of the Turkish translation and see if the mediating text had any influence on the translation. For this purpose, I first identified the mediating text in English. I found only one English translation of A Jangada de Pedra translated by Giovanni Pontiero from Portuguese into English in 1995 with the title The Stone Raft. The following examples 
(Excerpts 1 and 2), among many others, seem to verify my hypothesis that the Turkish translator's choices were significantly influenced by the mediating text in English.

\section{Excerpt 1}

Portuguese original: “..., muito verdadeiro é o novo ditado que diz, Quem contou um conto, de não contar outro se dará desconto." /..., the new saying is so true, The one telling a story would leave something out as long as they don't tell another one./2 (Saramago 1991, 808)

English translation: “..., all too true is the proverb that warns us, Don't count your chickens before they're hatched." (Saramago 1995, 100)

Turkish translation: “..., bizi uyaran şu atasözü ne kadar doğru, Tavuklarınızı yumurtadan çıkmadan saymayın." I..., how correct that proverb that warns us is, Don't count your chickens before they get out of the egg./ (Saramago 2017, 66)

\section{Excerpt 2}

Portuguese original: "Pararam para almoçar numa pequena casa de pasto à beira da estrada, ..." / They stopped to have lunch at a small roadside eating house,... / (Saramago 1991, 913)

English translation: "They stopped to have lunch at a snack bar at the roadside,..." (Saramago 1995, 271)

Turkish translation: "Yol kenarındaki bir snackbar’da öğle yemeği için durdular, ..." /They stopped at a snack bar by the road for lunch, .../ (Saramago 2017, 172)

Whether the translation of the original phrases into English and Turkish in the above examples is correct, adequate and/or acceptable or not is out of the scope of this paper, yet it can be observed that the proverb is translated literally from English into Turkish in Excerpt 1, and the word snackbar has been directly borrowed from the English text to render casa de pasto in Excerpt 2. It may be also necessary to mention here that none of these translation choices are normally used expressions in Turkish. There is a Turkish proverb, i.e., Dereyi görmeden paçaları sıvamak (to roll up the cuffs before seeing the stream), having the same meaning as the English proverb in Excerpt 1. On the other hand, casa de pasto refers to a modest restaurant like an

2 A gloss translation in English is provided by the author of this article for the texts in Portuguese and in Turkish. 
eating house or diner, and snackbar is not a commonly used expression to refer to this concept in Turkish.

In the following part the tenor is analyzed, comparing the selected dialogues from the ultimate ST in Portuguese, the mediating text in English, and the ultimate TT in Turkish. When comparing the register variables in the ultimate ST and the translations analyzed here, two levels of field and mode need to be considered: on the one hand, we deal with a written narrative work in the field of literature, which means the dialogues between the characters and the writer's address to the readers are non-natural but planned. On the other hand, the dialogues in the narrative occur between characters with their own personality features and socio-economic backgrounds in settings created by the author. Keeping this in mind, the shifts in tenor will be analyzed by comparing the forms of address used in a situational context where any age difference, familiarity, and hierarchy are the determining factor in the ultimate ST.

\section{Textual Comparison and Analysis}

In order to be able to conduct register analysis through the identification of forms of address, it is important to understand the relationship between the main characters of the novel. As mentioned before, there are five main characters in Saramago's novel that are somehow related to the separation of the Iberian Peninsula from the rest of Europe, and who come together as a result of a series of coincidences. To summarize briefly, everything starts with the line that Joana Carda draws on the floor with a stick of an oak tree. She is Portuguese, a young divorced woman who lives with her relatives in a small town in the midland of Portugal. At the same time when Joana Carda draws the line on the floor, Joaquim Sassa, an office worker living in Porto, lifts an absurdly heavy stone and throws it into the sea. Travelling to find answers to what happened to the peninsula, he meets José Anaiço, who is followed by a flock of starlings wherever he goes. José Anaiço is a young Portuguese man, teaching first graders at an elementary school in his little town. Another character is Pedro Orce, a pharmacist in Granada, who is sixty and thus the oldest in the group. The final character who joins to the group is Maria Guavaira, a widowed landowner in Galicia in her late thirties. Soon after the first female member joins the group, romantic relationships begin among the characters. The first couple to be formed is Joana Carda and José Anaiço, and the second is Maria Guavaira and Joaquim Sassa. However, feeling pity for Pedro Orce, the only single member of the group, Joana and Maria get involved with him on a single occasion only. Below the dialogues extracted from the novel and their translations are analyzed, considering these relations between the main characters and their given backgrounds, specifically based on age difference, familiarity, and hierarchy. 
Finally, examples from the translations of the parts where the author talks directly to the reader are analyzed.

The first example demonstrates how the dialogues between different age groups are formed in the Portuguese source text, and how this is rendered into English, and ultimately into Turkish. The dialogue ${ }^{3}$ below is exchanged between Joana Carda and Pedro Orce. This piece of dialogue has been chosen because it takes place between these characters towards the end of their journey after travelling, living, and even having sex together, once.

\section{Example $1^{4}$}

PT: "Sente-se mal, perguntou Joana Carda, Não, é outra coisa. [...], Que tem, diga se tem alguma dor, ..." /Do you feel [3rd person singular verb conjugation] bad, asked Joana Carda, No, it's something else, [...], What do you have [3rd person singular verb conjugation], tell [3rd person singular verb conjugation] if you have [3rd person singular verb conjugation] any pain, .../ (Saramago 1991, 1057)

EN: "Do you feel unwell, Joana Carda asked him. No, it's something else. [...]. What's the matter, tell us what you feel," (Saramago 1995, 501)

TR: "Kendini kötü mü hissediyorsun, diye sordu Joana Carda. Hayır, başka bir şey bu. [...] Sorun ne, bize ne hissettiğini söyle, ...”/Do you feel [2nd person singular verb conjugation] yourself [2nd person singular reflexive pronoun] bad, asked Joana Carda. No, this is something else. [...] What is the problem, tell [2nd person singular verb conjugation] us what you feel [2nd person singular verb conjugation], ..."/ (Saramago 2017, 315)

In the ultimate ST, Saramago uses the zero degree of deference (only the third person singular verbal form) to create conversations between these characters, which signals a neither distant nor too close relationship between them. This form of address was most probably chosen by Saramago because of the age difference between them: Pedro Orce is much older than the rest of the group. In contrast, in Turkish the tenor is informal, and all verbs are conjugated in the second person singular. This change in the tenor may have been caused by the mediating text since seeing no clue in the English translation the translator might have assumed that the characters would not talk in a formal way after their long companionship during their trip.

3 Note that Saramago does not use inverted commas or anything else to indicate dialogues in his novels. Starting a phrase with a capital simply signals a new speaker.

4 In all examples, the highlights in bold indicate the grammatical forms of address such as pronouns, verb conjugations in all three languages. 
A similar pattern is also observed in the dialogues between the characters that have newly met or between people who do not know each other at all. In Example 2 the interlocutors are complete strangers to each other, however, in Turkish, the translator still prefers to render it in an informal tone.

\section{Example 2}

PT: “..., Quanto quer para me levar à Europa, ..., Sabe, a Europa é longe como um raio," / ... How much do you want [3rd person singular verb conjugation] to take me to Europe, ..., You know [3rd person singular verb conjugation], Europe is far like hell/ (Saramago 1991, 784)

EN: “..., How much do you want to take me to Europe, ..., You know, Europe is a hell of a long way from here," (Saramago 1995, 73)

TR: “..., Beni Avrupaya kaça götürürsün ..., Biliyorsun, Avrupa buradan çok uzakta," /..., For how much do you take [2nd person singular verb conjugation] me to Europe, You know [2nd person singular verb conjugation] Europe is very far from here/ (Saramago 2017, 40)

When reading this dialogue, we do not have any background knowledge about the person who asks the price of the boat trip. Saramago just describes a scene where none of the main characters is involved. In this scene, people search for a way to get back to Europe, and Saramago includes their conversations with the person in charge of the boats in the novel. The captain asks for a high price, people refuse to pay it, and finally the captain tells them to cross to the other side swimming if they can. The interlocutors' use of zero degree of deference in the Portuguese original reflects the tense atmosphere of the scene where politeness is the least of concerns to the interlocutors. Translating from the English mediating text where the distance between interlocutors is not visible, the Turkish translator might have assumed the speakers would not talk in a formal and/or polite way under the circumstances. Although the Turkish translator chooses to neutralize the informal and vulgar language of the boat captain found in the English translation ("hell of a long way from here"), he still uses the informal verb conjugation when addressing the client.

In example 3, Pedro Orce meets an old man (Roque Lozano) on the mountain road. This dialogue occurs right after they see each other and exchange some words about the dog that is following Pedro. They still do not know each other's names at this point. However, Saramago informs the readers that Lozano appears to be the same age as Pedro. 


\section{Example 3}

PT: "[R.L.] Vossemecê é andaluz, conheço-lhe a fala, Venho de Orce, que é na província de Granada, Eu sou de Zufre, que é na província de Huelva, Bons olhos o vejam, Bons olhos o vejam a vossemecê, ..." /You [ $2^{\text {nd }}$ person singular formal pronoun] are [ $3^{\text {rd }}$ person singular verb conjugation] Andalusian, I recognize you [ $3^{\text {rd }}$ person singular object pronoun] from the speech, I come from Orce which is in the province of Granada, I am from Zufre which is in the province of Huelva, it is good to see you [ $3^{\text {rd }}$ person singular object pronoun], it is good to see you [ $3^{\text {rd }}$ person singular object pronoun $+3^{\text {rd }}$ person singular formal pronoun $], \ldots /$ (Saramago 1991, 1038)

EN: "You're from Andalusia, I can tell from your accent. I'm from Orce in the province of Granada. I hail from Zufre in the province of Huelva. Pleased to meet you, The pleasure's mine." (Saramago 1995, 583)

TR: "Endelüslüsün, şivenden anlaş1lyyor. Orceliyim, Granadadan. Ben de Zufreliyim, Huelva'dan. Tanıştığımıza memnun oldum. Asıl ben memnun oldum.” / You're [2nd person singular declension] from Andalusia, it is understood from your accent [2nd person singular possessive declension]. I'm from Orce, from Granada. And I am from Zufre, from Huelva. I am pleased that we met. In truth, I am pleased./ (Saramago 2017, 297)

In the above excerpt, Lozano addresses Pedro with the pronoun vossemecê and third person singular verbal form. Vossemecê is an old form of address which is still in use, especially by older people in some parts of Portugal. Unlike você, it is used to express respect, gratitude, and amicability. ${ }^{5}$ This title of respect, however, disappears in English, and as a result in the Turkish translation as well. Although the formal form of address in Turkish, that is siz and/or second person plural verb conjugation, would not be expected to be used within a rural context, if the translator had received some clue from the mediating source text, he might have combined the second person singular form conjugation with polite Turkish titles used for men, such as Efendi, or between men, such as Birader. Such a use would create a friendly tone between the two men, similar to the one found in the ultimate source text with the use of vossemecê.

Example 4 also demonstrates the difference in tenor between the ultimate source text and the ultimate target text, in Portuguese and Turkish, respectively.

5 https://ciberduvidas.iscte-iul.pt/consultorio/perguntas/voce-e-vossemece/14478 


\section{Example 4}

PT: “Agora vou-lhe contar o que me aconteceu." /Now I will tell you [ $3^{\text {rd }}$ person singular object pronoun] what happened to me./ (Saramago 1991, 861)

EN: "Let me tell you what happened to me." (Saramago 1995, 186)

TR: "Sana başıma geleni anlatayım." /Let me tell you $\left[2^{\text {nd }}\right.$ person singular object pronoun] what happened to me./ (Saramago 2017, 120)

This utterance takes place a short while after José Anaiço and Joana Carda meet each other for the first time. In this part of the book, Joana goes to the hotel where three men are staying and meets only José, because the other two are outside. After introducing herself and saying that she wants to talk about what happened to the peninsula, they leave the hotel and go to a nearby park to talk, and there the above-quoted sentence is the last thing Joana says before starting her story. Here, although the Turkish translator's choice may have been influenced by the lack of formality markers in English, it still sounds unnatural because of two issues. First of all, considering the socio-economic situation of the interlocutors, especially the fact that José is a young elementary school teacher, he would be expected to talk in a formal tone while addressing a person whom he has just met. Besides, even if we do not know the educational background of Joana, we would probably expect her to do the same. It is surprising that the characters of José and Joana use the formal tone in the Turkish translation until they go to the park and start talking again. Although they address each other formally in the ultimate source text throughout their whole conversation, José suddenly starts addressing Joana with the second person singular pronoun sen and related verb conjugations in Turkish when they get to the park, and she answers him back in the same tenor without having a prior mutual agreement to do so. Perhaps the translator assumed that they would adopt an informal tone because they suddenly got 'closer', being alone in a park.

Another excerpt in Example 5 once more exemplifies the change in formality between the Portuguese and Turkish texts. The speech in this example is directed to Maria Guavaira by a man working in her field. In Portuguese, the man addresses Maria using formal nominal and verbal forms of address, while in Turkish the tenor is again informal.

\section{Example 5}

PT: “..., A senhora devia era casar outra vez, precisa de um homem que lhe olhe pela casa, A senhora não encontrava, e não é por me gabar, um homem mais capaz do que eu, ...., A senhora acredite que gosto muito de si, A senhora, um dia destes, vê-me entrar pela porta dentro e olhe que será para ficar, A senhora 
faz-me perder a cabeça, a senhora julga que um homem é feito de pau, ..." /..., Madame should get [ $3^{\text {rd }}$ person singular conjugation] married again, you need [ $3^{\text {rd }}$ person singular conjugation] a man to look after the house, Madame would not find [ $3^{\text {rd }}$ person singular conjugation], and I don't brag, a man more capable than me, ..., Madame believe [ $2^{\text {nd }}$ person singular formal imperative] that I like you [ $3^{\text {rd }}$ person singular object pronoun] very much, Madame, one of these days, will see $\left[3^{\text {rd }}\right.$ person singular conjugation $]$ me enter through the door, and look $\left[2^{\text {nd }}\right.$ person singular formal imperative], it will be to stay, Madame is making $\left[3^{\text {rd }}\right.$ person singular conjugation $]$ me lose my head, madame thinks [ $3^{\text {rd }}$ person singular conjugation] that a man is made of wood, .../ (Saramago 1991, 932)

EN: “..., You should have remarried, you need a man to keep an eye on the house, no exaggeration, you couldn't have found a better man than me, ..., Believe me when I say I'm very fond of you, One day you'll see me come through that door and you'd better believe I'll be here to stay. You're driving me out of my mind, You think men have no feelings, that we're made of wood, ..." (Saramago 1995, 302)

TR: “..., Tekrar evlenmelisin, eve bakacak bir erkeğe ihtiyacın var, kesinlikle abartmıyorum, benden iyisini bulamazsın, ..., İnan bana senden hoşlandığımı söylerken samimiyim, Bir gün bu kapıdan girdiğimi göreceksin ve burada kalacağım. Beni çıldırtıyorsun, erkeklerin odundan yapıldıklarını ve duyguları olmadığını sanıyorsun, ..." $/ \ldots$, You should get married $\left[2^{\text {nd }}\right.$ person singular conjugation $]$ again, you need [ $2^{\text {nd }}$ person singular conjugation] a man to look after the house, I absolutely don't exaggerate, you can't find [ $2^{\text {nd }}$ person singular conjugation] anyone better than me, ..., Believe [ $2^{\text {nd }}$ person singular conjugation] me I am sincere when I say I like you [ $2^{\text {nd }}$ person singular object pronoun], One day you'll see $\left[2^{\text {nd }}\right.$ person singular conjugation] me entering through this door and I'll stay here. You drive me crazy [ $2^{\text {nd }}$ person singular conjugation], you think [ $2^{\text {nd }}$ person singular conjugation] that men are made out of wood and they don't have feelings, .../ (Saramago 2017, 191)

We can clearly see the lack of formal nominal forms such as $A$ senhora in both the English and Turkish translations. The similarity between the English and Turkish translations of the final sentence "a senhora julga que um homem é feito de pau", where the addition of "You think men have no feelings" in the English translation is transferred literally to the Turkish target text, proves the mediating role of the English translation. The lack of the use of the title in English makes the entire speech sound rude, patronizing, and even threatening in some parts (e.g., “...you'd better believe I'll be here to stay"), considering the hierarchical difference in status between two interlocutors. This of course can be a deliberate choice of the translator of the mediating text, however, it is clear that such a choice has influenced the Turkish TT. The same 
disappearance of respect and hierarchical difference between the characters is also visible in Turkish in the use of second person singular pronouns like senden and verbs conjugated in the second person singular forms such as evlenmelisin, inan, göreceksin.

The following example also shows how the mediating text causes the shifts between the Turkish translation and the Portuguese ST.

\section{Example 6}

PT: "Em desespero de causa e de ciência dizia o professor, Deixe lá, se a península der uma volta completa, o senhor verá o sol como via dantes, mas o aluno, desconfiado, respondeu, Então o senhor professor acha que tudo isto está acontecer para tudo ficar na mesma." /In despair of cause and science the teacher said, Let it be, if the peninsula has a complete turn, sir will see the sun as he used to see before, but the student, distrustful, answered, Then sir teacher thinks that all these are happening for everything to stay the same./ (Saramago 1991, 1033)

EN: "Seeing that he could not convince him with scientific arguments, the expert told him, Don't worry, if the peninsula turns all the way around you will see the sun as before, but the suspicious pupil rejoined, In other words, Mr. Know-it-all, you think all this is happening so that things can go back to being the same as before." (Saramago 1995, 464)

TR: "Uzman onu bilimsel açıllamalarla ikna edemeyeceğini anlayınca, Merak etme, dedi, eğer Yarımada sağa dönerse güneşi eskisi gibi görebileceksin, ama şüpheci öğrenci dedi ki, Demek bunun olduğuna inanıyorsun, yoksa işlerin eski haline dönmesinden bahsetmezdin Bay Çokbilmiş." /When the expert understood that he wouldn't be able persuade him with scientific explanations, Don't worry, he said, if the Peninsula turns right you will be able to see the sun like before, but the suspicious student said, So you believe, that this happened, otherwise you wouldn't talk, about things' turning to their old condition Mr. Know-it-all./ (Saramago 2017, 293)

In the passage quoted above, a layperson asks a scholar to explain how the sun has started to set where it used to rise. The scholar tries to explain that this is just an appearance, and that the sun continues to follow its normal trajectory, but the person does not understand. As seen in the excerpt, in Portuguese both adopt a formal way of address talking to each other with titles o senhor and o senhor professor. In English, however, not only does this formality disappear, but also the translator renders $o$ senhor professor with an ironic expression Mr. Know-it-all. This questionable choice of the translator, adding discourtesy to the original dialogue, has probably arisen from Saramago's previous passages where he uses o sábio and o senhor doutor talking about 
the scholar in a sarcastic way. This English translation was transferred with a similar, also ironic, expression in Turkish as Bay Çokbilmiş. In Turkey, professors' addressing their students with second person singular informal pronoun sen is common and acceptable, while it is unacceptable for students to address professors in such a way. Although the setting of this conversation is not academic, a layperson would still talk to a scholar in a polite and respectful way in a culture such as Turkey, where teachers and professors are greatly respected, especially in rural areas. Even if an uneducated person would not be expected to use the formal form of address with siz and/or second person verb conjugations, they would still address the scholar with Hocam, a title of deference for the people of knowledge like teachers, professors, scholars, and so on. If this dialogue had been translated directly from Portuguese, the choice of the translator would probably have been different.

The final examples, numbers 7 and 8 , focus on the narrator's addresses to the reader.

\section{Example 7}

PT: “Já se disse que são acasos, e manipulações, ..." /It is already said [impersonal passive voice with the pronoun se], that they are coincidences and manipulations,...l

EN: "As we have already observed, these are coincidences and manipulations, ..." (Saramago 1995, 68)

TR: "Daha önce de söylemiş olduğumuz gibi bunlar rastlantı ve manipülasyonlardır /As we said [1st person plural verb conjugation] before, these are coincidences and manipulations, ..."' (Saramago 2017, 46)

\section{Example 8}

PT: “..., não se pode chamar paisagem ao que os olhos vêem aqui, ...” /..., what eyes see here cannot be called [impersonal passive voice with the pronoun se] as landscape, .../ (Saramago 1991, 820)

EN: “..., you cannot refer to what one sees here as a landscape, ...” (Saramago 1995, 119)

TR: “..., burada görülen şeyleri bir yöre olarak adlandıramazsınız / you can’t name [2nd person plural verb conjugation] things that are seen here as a locality, .../ (Saramago 2017, 78) 
Example 7 demonstrates how the author's choice of impersonal form of narration becomes more inclusive in the translations: in English with the use of the pronoun we, and in Turkish with the first-person plural verb conjugation form. A similar strategy in the Portuguese original in Example 8, on the other hand, turns into a direct address to the reader with the use of you and related verb conjugation in English, and with the second person plural verb conjugation in Turkish. In both cases, the original sentences in Portuguese could be translated into Turkish adopting a similar impersonal passive structure without losses in the meaning or style.

\section{Conclusion}

This study has aimed to investigate the effect of an indirect translation from Portuguese to Turkish through a mediating translation in English, which lacks variety in the second person formal nominal, pronominal and verbal forms, on shifts in tenor in the target text, which can influence the interpersonal relations established within literary works, and thus cause different readings in source and target systems.

The passages taken from the English and Turkish translation of Saramago's novel $A$ Jangada de Pedra analyzed in this article show that the Turkish translator's choices have been influenced by the English mediating text. Without having access to the original text, the Turkish translator often changed the tenor of the text because he relied on the English translation where the formal forms have been omitted as in Example 5 or mistranslated as in Example 6. The study thus confirms Hadley's $(2017,3)$ claim that "if the first translation fails to retain any features that are culturally specific to the source text, subsequent translations' abilities to do so will be reduced".

Finally, these shifts in tenor create different interpersonal dynamics between the characters in the Turkish translation of Saramago's novel, and between the narrator and the reader, as illustrated in Examples 7 and 8, which directly influence the reading experience. However, if the aim is to preserve the original reading in terms of register and interpersonal relations, it becomes apparent that the English translation might not be the most suitable mediating text for source languages that use different grammatical forms to express different degrees of familiarity in forms of address. Since other translations are frequently available, perhaps choosing one as a mediating text in a language that preserves such differences more clearly (such as German, Italian, French, or Spanish) could be much more useful - at least as a secondary mediating text. 


\section{Acknowledgements}

This work is financed by the Fundação para a Ciência e a Tecnologia (FCT) with the grant number 2021.05834.bd.

\section{References}

\section{Primary Sources}

Saramago, José. 1986. A Jangada de Pedra. Lisboa: Editoria Caminho.

Saramago, José. 1991. "A Jangada de Pedra”. In Obras de José Saramago, Volume III, Romances, 747-1061. Porto: Lello \& Irmão Editores.

Saramago, José. 1995. The Stone Raft. Translated by Giovanni Pontiero. New York: A Harvest Book. Harcourt, Inc.

Saramago, José. 1999. Yitik Adanın Öyküsü. Translated by Dost Körpe. Istanbul: Gendaş Kültür.

Saramago, José. 2006. Yitik Adanın Öyküsü. Translated by Dost Körpe. Istanbul: Merkez / Turkuvaz.

Saramago, José. (2013) 2017. Yitik Adanın Öyküsü. Fifth Edition. Translated by Dost Körpe. Istanbul: Kırmızı Kedi.

\section{Secondary Sources}

Allen, Ana Sofia Ferreira. 2019. "O sistema de formas de tratamento em português europeu: Contributos para a compreensão da sua reestruturação a partir de textos escritos do século XX", MA Thesis. Lisboa: Universidade de Lisboa.

Arnaut, Ana Paula. 2014. "José Saramago: da realidade à utopia. O Homem como lugar onde". "O que transforma o mundo é a necessidade e não a utopia": Estudos sobre utopia e fição em José Saramago, edited by Burghard Baltrusch, 31-52. Berlin: Frank \& Timme.

Assis Rosa, Alexandra. 2000. "The Negotiation of Literary Dialogue (Translation). Forms of Address in Robinson Crusoe Translated into Portuguese." Target 12 (1): 31-62. 10.1075/target.12.1.03ass.

Assis Rosa Alexandra, Hanna Pieta, and Rita Bueno Maia. 2017. "Theoretical methodological and terminological issues regarding indirect translation: An overview." Translation Studies 10 (2): 113-32. https://doi.org/10.1080/14781700.2017.1285248.

Baubeta, Patricia Anne Odber de. 1992. "Modes of Address: Translation Strategies or the Black Hole." Ilha do Desterro 28: 87-107.

Brown, Roger, and Albert Gilman. 1960. "The Pronouns of Power and Solidarity". In Style in Language, edited by Thomas Albert Sebeok, 253-76. Cambridge, Mass.: MIT Press. 
Carreira, Maria Helena Araujo. 1997. Modalisation linguistique en situation d'interlocution: proxémique verbale et modalités en portugais. Louvain-Paris: Peeters.

Carreira, Maria Helena Araujo. 2001. Semântica e discurso, estudos de Linguística Portuguesa e Compa-rativa (Português/Francês). Porto: Porto Editora.

Carreira, Maria Helena Araujo. 2002. "La désignation de l'autre en portugais européen: instabilités linguistiques et variations discursives". In Instabilités linguistiques dans les langues romanes, Travaux et Documents, no 16. Paris, edited by Maria Helena Araujo Carreira, 173-84. Saint Denis: Université Paris 8:

Carreira, Maria Helena Araujo. 2004. "Les formes d’allocution du portugais européen: valeurs et fonctionnements discursifs." Franco-British Studies, 35-45. Accessed February 9, 2021. http://cvc.cervantes.es/obref/coloquio_paris/ponencias/pdf/cvc_araujo.pdf.

Carreira, Maria Helena Araujo. 2007. "Le pronom d'adresse portugais «você»: valeurs et évolution". In Studii de lingvisticã oi filologie romanicã. Hommages offerts à Sanda Reinheimer Rîpeanu, edited by Alexandra Cuniță, Coman Lupu and Liliane Tasmowski, 15-9. Bucharest: Editura Universităţii din Bucureşti.

Cunha, Celso, and Luís F. Lindley Cintra. 2014. Nova Gramática do Português Contemporâneo. Porto: Edições João Sá de Costa.

Dinçkan, Yeşim Sönmez. 2019. "A Linguistic Analysis of the Literary Translation of Address Forms from English into Turkish". Çeviribilim ve Uygulamaları Dergisi, Journal of Translation Studies 27: 89-110. https://doi.org/10.37599/ceviri.583256.

Duarte, Isabel Margarida. 2011. "Formas de tratamento em português: entre léxico e discurso”. Matraga 18 (28): 84-101. Accessed February 9, 2020. https://www.researchgate. net/publication/277476118_Formas_de_tratamento_em_portugues_entre_lexico_e_ discurso_in_Matraga_Vol_18_n_28_Rio_de_Janeiro_UERJ_2011_pp_84-101.

Göksel, Aslı, and Celia Kerslake. 2005. Turkish: Comprehensive Grammar. London and New York: Routledge.

Hadley, James. 2017. "Indirect translation and discursive identity: Proposing the concatenation effect hypothesis." Translation Studies 10 (2): 183-97. https://www.tandfonline. com/doi/full/10.1080/14781700.2016.1273794

Halliday, Michael Alexander Kirkwood, Angus McIntosh, and Peter Strevens. 1964. The Linguistic Sciences and Language Teaching. London and New York: Longman.

Hatim, Basil, and Mason, Ian. 1990. Discourse and the translator. London and New York: Longman.

Hatipoğlu, Çiler. 2008. "Analysis of the Social Meanings of the Second Person Pronoun SEN in Turkish.” Dilbilim Araştırmaları, 15-29. Accessed October 6, 2021. http://dad. boun.edu.tr/en/download/article-file/224703.

İmamova, Holida. 2010. Türkiye Türkçesi ile Özbek Türkçesinde Nezaket Anlamı Taşıyan Seslenmeler. A. Ü. Türkiyat Araştırmaları Enstitüsü Dergisi 42: 1-10. Accessed February 9, 2021. https://dergipark.org.tr/en/download/article-file/33486. 
Kaya, Emel Kökpınar. 2012. An analysis of the addressing terms used in Turkish society in the interface of alienation and intimacy. Studia Uralo-Altaica 49: 303-09. Accessed October 6, 2021. https://ojs.bibl.u-szeged.hu/index.php/stualtaica/article/view/13681.

Keser, Burcu Meliha. 2018. "Nezaket, Nezaket Teorileri ve Türkçede Kullanılan Nezaket Kavramları." TÜRÜK, Uluslararası Dil, Edebiyat ve Halkbilimi Araştırmaları Dergisi 15: 127-38. Accessed February 9, 2021. http://www.turukdergisi.com/Makaleler/935436085_18\%20B.\%20KESER\%20127-138.pdf.pdf.

Lewis, Geoffrey. 2000. Turkish Grammar: Second Edition. Oxford: Oxford University Press. Lopes, Sara Morgadinho. 2017. "Representações e usos das formas de tratamento por rececionistas de hotel." Simpósio 51 - O ensino de língua portuguesa na formação profissional. 10.1285/i9788883051272p4121.

Lucena, Maria Inêz Probst. 1997. "A Brief Analysis of Forms of Address in the Translation of Animal Farm." Cadernos de tradução 1 (2): 188-96. Accessed October 6, 2021. https://dialnet.unirioja.es/servlet/articulo? codigo $=4925588$

Manole, Veronica. 2011. "Usos de formas de tratamento alocutivo do português e do romeno em contexto profissional." XVI Congresso Internacional de la ALFAL - Alcalá 2011. Accessed February 9, 2021. https://www.researchgate.net/publication/258512357_ Usos_de_formas_de_tratamento_alocutivo_do_portugues_e_do_romeno_em_contexto_profissional.

Mansor, Nor Shahila. 2018. "Understanding the translation of second person address form in the specific context." Revista Internacional de Lenguas Extranjeras 8: 65-89. 10.17345/rile08.65-89.

Meister, Lova. 2014. "The T/V dilemma: Forms of address as a stylistic resource in English-Swedish subtitling." Perspectives 24 (4): 527-42. DOI

Munday, Jeremy, and Meifang Zhang, eds. 2017. Discourse Analysis in Translation Studies. Amsterdam and Philadelphia: John Benjamins Publishing.

Nascimento, Maria Fernanda Bacelar do, and Amália Mendes, and Maria Eugênia Lammoglia Duarte. 2018. "Sobre Formas de tratamento no português europeu e brasileiro." Diadorim, Rio de Janeiro 20: 245-62. file:///Users/imrengokce/Downloads/2327670297-1-PB.pdf.

Pazos-Justo, Carlos. 2017. "A Jangada de Pedra de José Saramago: repertório e sistema interliterário ibérico." Revista De Estudos Saramaguianos 5 (janeiro): 12-23. https:// estudossaramaguianos.files.wordpress.com/2020/04/revista-de-estudos-saramaguianos-portugues-n-5-carlos-pazos-justo.pdf

Pratas, Sara Alexandra Pinto. 2017. "As formas de tratamento e o ensino de português como língua não materna." MA thesis, Coimbra: Universidade de Coimbra.

Santos, Quênia Regina Matos dos. 2019. “José Saramago - Do Romance Historiográfico ai Alegórico: A Recepção de sua Ficção.” PhD diss., Porto Alegre: Universidade Federal Do Rio Grande Do Sul, Instituto De Letras. 
Szarkowska, Agnieszka. 2013. Forms of Address in Polish-English Subtitling. Berlin: Peter Lang.

Taavitsainen, Irma, and Andreas H. Jucker, eds. 2003. Diachronic Perspectives on Address Term Systems. Amsterdam and Philadelphia: John Benjamins Publishing.

\section{About the author}

İmren Gökce Vaz de Carvalho has MA and BA degrees in English-Turkish Translation and Interpreting Studies. She is currently pursuing a $\mathrm{PhD}$ in the inter-university doctoral program in Translation and Terminology coordinated by Universidade Nova de Lisboa and Universidade de Aveiro. She does literary, legal, and technical translations from English and Portuguese into Turkish. She is also a certified teacher of Turkish as a foreign language. Her research interests include literary translation, retranslation, reception of translation, indirect translation, legal translation, the role of the translator and interpreter, sign language interpreting and accessibility. 